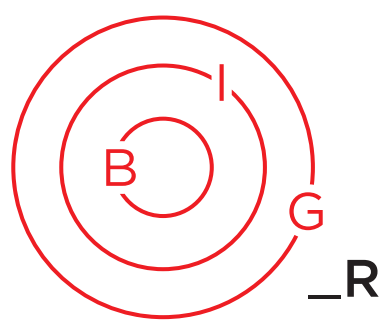

ARTICLE SPECIAL SECTION

\title{
Rohingya Refugees in South Asia: An Exploration of Social Borders and the Margins
}

\author{
Rachel Irene D’Silva *
}

By reviewing the case of the Rohingya, a marginalized community in the postcolonial state of Myanmar, this article (as part of a special section on South Asian border studies) explores the perspective of Rohingya refugees and conceptualizes social borders from the voices of the refugees. Juxtaposing postcolonial borders with narrations of Rohingya in India brings out the politics of the marginalized communities in the country's borderlands. The article shows how borderscapes are shaped for refugees that articulate ideas of social justice and recognition. Building on international studies of the Rohingya, I conducted fieldwork into the situation of the Rohingya in India. The resulting interviews add to our understanding of Rohingya refugees and address a scarcity of literature on the Rohingya in border studies. Through the analysis, I discover the history of the Rohingya identity in Myanmar, which contextualizes their statelessness. Social borders and state legislation reinforce barriers to citizenship and sharpen the exclusion of migrants, refugees, and other stateless peoples in South Asia.

Keywords: South Asia, Refugees, Rohingya, post-colonial states, boundaries, borders, margins, Southeast Asia, marginal communities.

\section{Introduction:}

As an ethnic, religious, and linguistic minority in Myanmar, the Rohingya have been stateless for almost four decades (since 1982). The Myanmar state discriminates against them and imposes severe restrictions on their activities. They are denied the right to nationality and citizenship by Myanmar and, therefore, they are forced into statelessness. Their lives in Myanmar depend on the legal status of temporary papers. In 2017, they were forced out of their villages and towns through violence. They face severe restrictions on movement, culture, everyday life, and access to education by the state. The 1982 law on citizenship excludes them as national people. Throughout history, they were repeatedly displaced into neighbouring Bangladesh by the state. Since the late 1990s, there has been a massive exodus of Rohingya to Bangladesh as a result of persecution, torture, and killing in Myanmar. In the host country, they are yet to gain access to refugee recognition and resettlement rights. In November of 2021, hundreds of refugees were relocated to an island in the Bay of Bengal by Bangladesh (AP 2021).

Migrants and refugees in India, such as Rohingya who are considered illegal by the state, have been understudied in border studies. They face statelessness and lack sufficient protections. In the context of forced migration, this paper asks: what types of borders confront Rohingya refugees? First, the introductory section summarizes the international plight of Rohingya refugees in the context of border studies and

\footnotetext{
* Rachel Irene D’Silva MA in Politics, PhD candidate in Social Management, Central University of Gujarat, India. Email: rchldsilva@gmail.com
} 
borderscapes in particular. The second section outlines the methodology of the study. The third section highlights the current situation of Rohingya in India. Section four expands on the history of the Rohingya and explains borders of identity and belonging through the voices of Rohingya refugees as they discuss the threat they face in Myanmar. Section five shows the processes of marginalization, as demonstrated in accounts of exclusion from citizenship and violations of human rights. Section six explains bordering processes based on national law, which have led to restrictions and curbing of religious freedom and even mass attrocities. Finally, section seven highlights the borderlines of the marginalized Rohingya refugees in the state of exceptionality and subjectivity. This entire exploration of marginalization shows that the situation faced by Rohingua refugees arrises from their condition of forced migration.

Marginality in South Asia can be studied by linking borders to spaces and processes at the margins of the community (Cons \& Sanyal, 2013). Narratives of marginalization are not just about borders but are also essential to forging and asserting the community, a sense of belonging, and internal boundaries (Cons \& Sanyal 2013; Cons 2013). Margins conceptualized here are the lived margins by Rohingya refugees in the internal boundaries. Rohingya refugees face discrimination due to identity politics. This experience of discrimination is manifested in dire poverty among refugees, poor living arrangements, shortfalls in protections, standards, and humanitarian assistance that are internationally prescribed.

The word 'borderscape' typically refers to borders that are formed by a collection of regulations, semantics, and other practices and discourses that constitute the border itself. In the social sciences the word 'borderscape' means the geopolitical interactions of exchanges between different (affirmative and subversive) practices of border control and various types of social or cultural formations, discursive processes, and individual identity policies (University of Luxembourg 2005). The conceptualization of borderscapes also includes what is permitted, culturally and socially prohibited, and artistically justifiable, as well as the borders of artworks, buildings, or concepts, and the borders given by individuals and language (University of Luxembourg 2015).

Borders as marginal spaces at the edge of a nation continue to be both problematic and central to national and state politics throughout the region (Cons 2013). Borders are situated in dialogue with other kinds of spaces and practices as well as with centres. Processes of bordering are replicated in the margins that are away from the borders. Borders are articulated in how forms of state recognition are not only central to the formation of identity, but also in how states co-opt these forms of 'grey spacing' through flexible forms of 'border citizenship' (Cons \& Sanyal 2013). The literature on margins and borders is often from the perspective of state sovereignty. Internal borders are made from experiencing belonging and unbelonging, making and un-making, and the illegalization in everyday life for refugees in sanctuary cities (Fakhrashrafi et al. 2019). In this context, there is limited literature on the making of social borders, or borders within society.

\section{Methodology}

This research is a pilot study based on fieldwork completed as part of my $\mathrm{PhD}$ research. From news reports, it was evident that the Rohingya refugees were very vulnerable. For example the Indian Express carried a feature on Rohingya refugees living in India (Express News Service 2018). However there was lack of information on refugee protection and status for Rohingya aimed at dealing with such vulnerability. The report on Rohingya refugees described the settlements, access to education and livelihoods in Mewat and Hyderabad (Fields et al. 2019). As part of a study on urban refugee livelihoods the Women's Refugee Commission did a field assessment of the economic coping strategies where they interviewed key stakeholders from service providers, donors, and refugee communities. Their findings reflect the many voices and perspectives gleaned through the interviews, project sites, visits, focus group discussions (Women's Refugee Commission 2011).

From the pilot study, I learned about the identity and statelessness of the Rohingya peoples (including not being duly recognized by the host government). Samaddar states,

Therefore the post-colonial commentaries on statelessness are studies of permanent incompleteness-a reality that always seems to fall short of a hyper-reality, and therefore the ideal reality, of citizenship, entitlements, legal protection, full proof identity, solemn recognitions by courts of law, and the avowals by the state (2016, 102).

I visited Hyderabad-a city in south central India where a sizeable Rohingya settlement is found today. This led me to explore how Burma Rohingya refugees arrived and settled here.

During the pilot study, with the support of a local guide, I interviewed refugees and care workers. Information was sought on the legal protections of Rohingya refugees and on the role of other stakeholders. Interviewees were asked about how they felt in the city, and they generally responded positively on living conditions compared to the situation they faced back home. Also, they expressed comfort that their children were being supported in education by NGOs, government schools, and madrassas. We asked care workers why they came to Hyderabad as refugees. They said that growing urbanization, in particular the outskirt region where the Rohingya have settled, were factors in why they migrated 
here. Overall, we learned how their statelessness impacts their protection in the country. This study presents the voices of six of the refugees who gave interviews.

\section{Rohingya Refugees in India: Presumed Illegality and Associated Risks}

In interviews conducted in June 2019, Noor Mohammed, Abdul Alam, Zakir Hussain (Rohingya refugees in Delhi) expressed their stories and discussed their situations as follows. Noor Mohammed was in Saharanpur, in Uttar Pradesh for 25 years. His family consists of eight people: two children in school, two auto rickshaw drivers, and two are looking for jobs. He got a UNHCR refugee card in 2013 and works as a vegetable vendor where he buys vegetable from Okhla Mandi (wholesale market) and sells them locally. Abdul Alam works as construction labourer or daily wager. Zakir Hussain sells fish purchased from Ghazipur mandi to people and refugees in Faridabad and Kanchan Kunj. The average income earned by the three men is 6000 to 8000 rupees.

They are currently put up at Shaheen Baug extension in the settlement known as Shram Vihar where they live among 25 to 30 Indian families. The landlord sold off the land. Some people purchased plots and rented them out to refugees on the land. Currently, they pay 2000 rupees in which three families live together in about 300 square meters. Previous rates have been as low as 500 rupees for 100 square meters. Sanitation infrastructure is non-existent and the toilet is the sewer. They have one toilet for 95 refugee families. They cannot build concrete structures on the land and the land officers do not permit concrete construction. Part of the land belongs to Delhi Development Authority and part to Uttar Pradesh irrigation department. They are inhabitants in an enclave.

This community is served by UNHCR which supplies one female volunteer, a youth club, a stitching centre, and a medical clinic service provider. An additional stitching centre is run by an NGO. Children do rag-picking occasionally. There are two disabled persons. They have one sick person. They need a good place to stay. A report on the experiences of Rohingya found that Rohingya families face sudden evictions and non-renewal of informal leases (Brenner 2019). The Rohingya also face food scarcity due to inadequate income (Brenner 2019). The Rohingyas work as 'ragpickers, collect scrap, work in wholesale vegetable and fruit mandis, shops and even local industrial estates in Jammu city and its outskirts' (Express News Service 2018). To the Indian government, the Rohingya living in India are "illegal". The Supreme Court recently issued notice to the Centre and to states providing aid to all refugees and asylum seekers (Jain 2021). The Court allowed nearly 150 Rohingyas detained in the holding centres in Jammu to be deportated to their parent country, as per the procedure of law (Live Law News Network 2021).
The Human Rights Law Network (HRLN) posted a YouTube video of the massive fire in the Rohingya settlements of Madanpur, Khadar in Delhi in June 2021 that burnt down 54 shanties making 250 refugee families homeless (Abdali 2021). The following is a brief summary of the video footage on the "Continuing Exodus of Rohingya to India" by Human Rights Law Network (HRLN) describing the incident. The commentator explains that the refugees come from Myanmar. They went to India to save their lives and seek refugee protection by registering with the UNHCR as refugees. The fire destroyed basic necessities. Families lacked food, water, and clothing. Women and children were on the road all night, shocked and helpless. In 2013, HRLN, conducted a fact-finding operation and found that Rohingya settlements in Delhi and Haryana were "sub-human conditions". They had no food, no water to drink, no access to education, and no access to healthcare services. Since 2018, they have noticed that fires have broken out eight times in different settlements in Delhi, Haryana, and Jammu. Destruction is always preceded by threats before colonies are burned down. These refugees are under threat and culprits are responsible for the fires. A Twitter handle claimed, "Yes we did and we do again. Hashtag rohingyaquitindia". This indicates the severity of the risk they face.

\subsection{Life in Exile}

Rohingya voices: Zakir Mohammed, head of Camp N. 1 Balapur, Hyderabad, India:

The name of the camp is Bismillah settlement, a new camp that came into existence in 2018. There are 22 Camps in Balapur. Camp 1 includes 64 families and 230 members. We have camps big and small. An individual named Assim Bhai gave them the land. He takes charge of the place. They pay 20,000 rupees to rent some land in Balapur.

\section{The Making of Social Borders}

Politics of borders are linked to geographical, social, and spatial margins in South Asia (Cons \& Sanyal 2013). In Myanmar, the state has publicly restricted the use of the word 'Rohingya' since it means inhabitants of Rohang, an early name for Arakan. The official position is that this community is from Bangladesh and therefore must be called Bengali. The Rakhine Buddhist are the ethnic majority in Arakan and speak a dialect of Burmese. The regions of Chittagong of South-eastern Bangladesh and Arakan saw an influx of Muslim Arab merchants in 9th century. Rohingyas claim descendancy from the first Muslim Bengalis, Muslims, Persians, Moghuls, Turks, and Pathans (Lewa 2008). According to Zarni, despite Aung Sang Syu Kyi's professed commitment to democracy and human rights, she has practiced the same policy of chauvinistic nationalism that alienated 
minorities (as cited in IMPRI Impact and Policy Research Institute 2021). In international law, a stateless person is a person who is not considered a national by any state under operation of its law. As such, the Rohingya are considered a stateless people.

In order to understand how residents of border zones navigate and negotiate risk, it is necessary to be rooted in the histories, complexities, and contexts which are not formed in isolation, but rather are relative to a broader system of marginalized and marginalizing spaces, processes, and patterns (Cons \& Sanyal 2013). The macro boundaries within the histories of the post-colonial state are understood by analysing the literature on the Rohingya based on the histories of the colonial period. This paper uses the optics of internal boundaries to explain borders. The "stateless Rohingya" needs to be viewed through the lens of histories where nation-state politics creates the problem. The Rohingya are denied rightful national membership or citizenship as an indigenous race, but the histories and colonial boundaries bring out the politics of negotiating with state and the non-state actors in Myanmar.

\subsection{Politics of Identity of the Rohingyas}

The colonial systems and their implications influence politics of identity and ethnicity. The politics of identity of the Rohingyas also affects the formation of internal borders which are based on ethnicity. The term "Rohingya" is based on their belief as the inhabitants of the Arakan region. ${ }^{1}$ Those who identify by this term Rohingya mean they are 'native' to Arakan region. The claim of Rohingya lies in the Arakan country, history, identity, culture, religion, communities and geography. But the Rohingya are contested due to the fact that they claim independence and the right to representation of ethnic minorities in the political affairs of Myanmar. The notion of citizenship in the Burma/Myanmar state based on indigeneity is tied to the politics of ethnicity and political representation, and the Burma/Myanmar state has strong claims against the Rohingya identity (Thawnghmung 2016).

Rohingya self-identify with "Ruaingga" (Leider 2014). "Rohingya" in the popular language is the name of 'Arakan'. The nomenclature, Rohingya is cultural. The Arakan region has a rich history of cultural exchanges among religions. It also served as the seat of Buddhism and syncretism, a culture of Vaishnavism and Persian. The Arakan region was ruled by various dynasties. The colonial conquest of Rakhine and Burma changed the demographic of the region. After the Burmese took over the Arakan people, they fled to Chittagong. This has also caused conflict as a result of demographic changes and resource control. When the census conducted in the 1930s in Burma categorized people into different groups based on ethnicity there were riots amongst the people.
Rohingya are native to the Rakhine State of Myanmar. Their origins can be traced to the present-day territory prior to British annexation of Burma in 1824. This issue has been the subject of many discussions on the part of the elites in Myanmar and a number of historians have contributed to this debate. Historian Kei Nomoto discussed the presence of the Rohingya in Rakhine since the 8th century which might help to establish their claim to a Rakhine State. That view is challenged by historian Aye Chan. The 'Development of a Muslim Enclave' in Rakhine the State of Burma (Myanmar), Chan discusses the various events throughout the history of the region-particularly the events of colonial Burma including the mass migration of people from the neighbouring Bengal region under the British rule. His key argument is that the 'Muslim identity' in Rakhine is a historical development constructed by migration under the various regimes (i.e. Burmese, British) that held power primarily during the 18th and 19th centuries. This sheds light on Chittagong's migration to the region and the development of community violence across ethnic lines. Chan notes that those who call themselves Rohingyas reside at the Mayu border, in the townships of Maugdaw and Butitaung, which are descendants of Chittagonian immigrants and that they are different from other Muslim communities in Arakan who live in other townships. It provides evidence to demonstrate how the people of the Mayu border were referred to the Chittagonians in British colonial records. His viewpoint could be complemented by Leider's analysis on the Rohingya in Myanmar. Leider mentions that a certain section of the people from the northern region of Arakan began to identify as 'Rohingya' which then led to the movement of ethnic identification of the Rohingya (Leider 2014).

Historical records also mention that the 15th century kingdom of Marak $U$ extended to the ancient Indian subcontinent. The descendants of the Muslim communities of Arakan during the time of Marak $U$ lived in the Marak $U$ and Kyauktaw Townships from 1430 to 1784. Another periodic reference to a Muslim presence is the retinues of the Sultan of Bengal who were the earliest Muslim settlers in the region, dating back from 1430 to 1784 . Histories showed how the term Rohingya becomes politicized by the 1950's movement to create an autonomous Muslim zone in Rakhine State. Similarly, the creation of the Jamiyyat al ulama of the Rohingya in 1936 under British domination is proof of the emergence of a Muslim movement in Arakan. The origins of the mujahideen movement in Rakhine bears witness to the disappointment of Muslims who tried to integrate the cantons of Buthidaung, Maugdaw, and Ratheedaung in Pakistan and ended up in revolt. The rebels who declared holy war on the new Republic called themselves Mujahedin (Chan 2005). In the case of the Rakhine State People's Council, the testimony of the inability to resettle in the villages after fleeing the Japanese occupation led to the Mujahideen rebellion. 
Muslims made several attempts to gain entry into the political affairs of the state of Burma as a Muslim ethnic nationality and legal status to be given to the Mujahid party. In the 1960s, under Burmese Prime Minister $U$ $\mathrm{Nu}$, Muslims called for establishing the Rohingya state. Efforts have been made to obtain recognition of their ethnic identity in the Union of Burma and to obtain the equality of status enjoyed by other ethnic groups. They firmly insisted on their identity as Rohingyas after the Bangladesh gained independence as Dhaka followed the policy of disowning the Chittagonians who were in favour of West Pakistan (Chan 2005).

While there are debates as to whether or not Rohingya originated in Burma before the British annexation, census records of Burma show the formation of 'ethnicity' as a social and political construct that was established under colonial rule. In particular, an Indian ethnicity (referred to as Ko La in historical records and scholarly articles on Arakan) was recorded by the British in the Arakan region after the arrival of slaves from Bengal (Chan 2005).

The development of economic frontiers in Arakan under the British annexation policy encouraged agriculturalists who were said to be residents of Bengal to come from areas around the Arakan, a development that shifted the social boundaries in Burma's society. Another racial division began to develop on the lines of ethnic difference with Chittagonian immigrants becoming ethnically dominant in number in the Mayu border under British rule. The report on the settlement operation in Akyab District mentions the comparative tension between the Bengali and the Arakanese race. The racial classifications established by the British census (including categories such as Mahommedean, Burmese, Arakanese, Shan, Hill Tribes, and Others) are proof of the emergence of racial identities in this time period. After the census in 1921 that classified Indian as separate group of people, the first Anti-Indian riots took place in Burma. Chan (2005) states that all Chittagonians and Muslims were recorded as Mohammedan under column of 'Race' in several census reports of 1871, 1901 and 1911.

Categorizing populations under British religion and ethnicites created limits that determined people's ability to access resources in society. These ethnic divisions still have an impact on Myanmar's society. For instance, in 2016 and 2017, ethnic cleansing operations by the state in an attempt to drive Rohingya people out were reported. Despite the national challenge to the identity of the Rohingya, we cannot deny them in Myanmar. The "South Asian ethnicity", as defined in the British records, referred to the Chittagonians of Bengali until the 1990s thus registering them as Muslims and considering them persons of Indian ancestry.

The case of the Rohingya indicates that the politics of identity of the Rohingya was built in a socio-spatial context. Through the various powers and rules it has undergone alterations. The second part of this section highlights politically mediated identity formation of Rohingya under post-colonial state regimes-starting during the early democratic rule of Independent Burma and tracing through the military coup and the military run democratic government in Myanmar. It was in this post-colonial period that army General Ne Win's Burma Citizenship Law effectively rendered the Rohingyas stateless. He excluded generations that regarded themselves as a Rohingya people although he was viewed differently by military leaders. They became stateless and their community identity was adversely affected by the law (Farzana 2017).

\subsection{Rohingya Refugees voices: Threat to Identity}

Rohingya voices: Akhtar, 24 (Rohingya interpreter at UNHCR, female):

The village is called Nayan Chaw. Since we have lived there, we have lived under a lot of restrictions. The government is creating restrictions, as far as Musalman is concerned. After studying and after finishing class ten, there are difficulties to go to college. We have no right to go to university. There is a pass which we cannot obtain. To go from one village to the other too we must take permission. If a girl wants to see her dad, she needs permission. She can stay no longer than a day. We have to pay 500, 600, 1000 to have permission. We had to deal with that type of restriction in Burma. As we were born there, in that place, we continued to live there for our love for the country. People feel a different way about their country. They kept us like a bunch of animals. For cutting timber we need permission, for cutting bamboo we need permission. We have to get permission to farm on our own land. There are mostly famers there.

\subsection{Rohingya Statelessness and Post-coloniality}

Samaddar (quoted in IWM Vienna 2019) states that the surge in de facto statelessness in Myanmar is due to nationality issues that have been more "ethnicized" and "securitized". He argues that international conventions on statelessness do not acknowledge the problem of statelessness in this manner. The British practice of colonial labour in different countries created statelessness for plantation labours in Sri Lanka. The same was true of the Rohingya. Samaddar (2019) observes that the nearly a million tea plantation workers that were taken from the southern part of India ended as disenfranchised. The issue of Sri Lankan Tamil ethnicity in Sri Lanka started with Tamil plantations labour of Indian origin. He contends that post-colonialism created the problem of statelessness not addressed by the 1954 Convention. Critical postcolonial approaches to forced migration analyse contemporary forced migration using concepts such as "borders". According to Samaddar (2016) postcolonial perspective of forced migration includes 
the combined exceptionality of the events of forced migration with the structure and the daily experiences of colonialism, decolonisation, and the post-colonial realities of society and politics. According to Samaddar (2016) post-colonial perspective of forced migration includes the combined exceptionality of the events of forced migration with the structure and the daily experiences of colonialism, decolonisation, and the post-colonial realities of society and politics. In South Asia, post-coloniality has shaped borders around belonging and citizenship.

\section{Migrant Historicity}

The continuous movement of Bengali-speaking Muslims from Bengal, particularly Chittagong, to Rakhine (Burma or Myanmar) contributed to the statelessness of the Rohingya whose Muslim origins were noted in Rakhine in 16th through 18th centuries, as per Dutch and British sources (Gosh 2016, 25-26). The descendants of Bengali slaves were there among many of them. Bengali and local were not distinct, though the Bengali would have retained their mother tongue. Additionally, during the British occupation of Rakhine in 1825 and the signing of the Yandabo Treaty the following year, Rakhines returned home as well. As such, new Chittagongians who were attracted by the commercialization of rice cultivation and by the opportunities to work could have entered Rakhine. The development of Akyab port by the British for a century or more under the British until Burma was separated from the Indian Empire in 1937 in the future provided additional opportunities as well (Gosh 2016, 26; Leider 2013).

The Indian partition event may have added another dimension to the immigration issue as a large number of Bengalis, most of whom had been in Rakhine province, demanded either political status as part of Pakistan or demanded an independent nation (Gosh 2016). Gosh notes that Pakistan's vision did not bear fruit as the political leaders Jinnah and Aung Sang of Burma had entered into an agreement before partition in July 1947 through which they chose to not alter their international border at the Naf River (Gosh 2016, 26; Leider 2013).

In 2014, the Government of Myanmar continued the census exercise established in 1983 and kept the Rohingyas outside its scope because the government insisted they should identify as 'Bengalis' (an ascribed group identity) and not 'Rohingyas' (a term that historically defined them). The term 'Bengalis' is more linguistic in nature while the term 'Rohingyas' may hold a more religious connotation. The political situation of the Buddhist-Muslim conflict in the country makes the "religious" identity an important cause of exclusion (Gosh 2016, 27).

\subsection{Citizenship and human rights?}

Rohingya voices: Samira (interpreter at UNHCR, woman):

We don't have an ID. They kept us temporarily there. Children from all denominations study in the classroom. There is bias towards Buddhist study within the school. If we do something, they take us to the police station.

Here, children are allowed to study. We cannot remain in Burma as we do here. There is no contact with the local population. We came out of fear. We had to go through the mountain when the violence started in Akyab. I was involved with an UNHCR BMLRC in Burma. Violence broke out in Sittwe. People at the mosque were murdered. I have already lived in Bangladesh for 2 months. We are not allowed to make the appeal of prayer (Azaan) and are not allowed to pray (Namaaz). They beat up two people praying they nearly died. They're taking people to a police station.

We have no documents. My mother brought us up with so much difficulty. My mum used to work with UNHCR. We have temporary papers. We have a temporary I.D. There are those who don't have a husband or children, who live alone and are old. Some young children with no one with them also commit suicide. To give a single prayer call, it is very difficult. Even to follow the true religion, that's hard. You have an identification card. We don't have an ID. We live as temporary individuals. We still live the way they want us to live because where else should we go. Where should we go from here? Yet they commit so many atrocities against us.

On crossing the border:

It took four hours to cross that border. At some side there is 1 hour road, another side there is two or three hour road and some side have two days road to the border. I belong to Maungdaw of Khamung. I arrived June 12, 2013. I came by boat to the border. I came to Balughat and took a bus to the Indian border, then train to India. We had to come with no food.

\section{Ethno-religious boundaries of Myanmar}

Refugees were often termed by States as "economic migrants" or "illegal settlers". The politics of sub-nationalism, nationalism, and nationhood as decolonizing processes produced postcolonial borders and boundaries in the states. In South Asia states, postcoloniality impacted the implementation of citizenship and belonging for groups of refugees and migrants.

In Myanmar's ethnoreligious politics, the Rohingya are identified as Bengali immigrants by Rakhine Buddhists. The presence of East Bengali/ Chittagonian/ Rohingya refugees means one thing in the international political 
context. However, being seen as Rohingya is different, something which the politically active section of the Rohingya community wants to be acknowledged as. Furthermore, in Buddhist-Rohingya politics Buddhists claim the Rohingya to be Bengali-speaking immigrants who have to return to where they came from, which is Bangladesh. The Rohingya assert themselves as an ethnic community in this context and seek regional autonomy. They demand cessation from Myanmar through the creation of a Rohingya state (Gosh 2016, 119-121).

\subsection{Politics of nationalism of Burma/Myanmar}

In the Burmese State, the Rohingya face oppression for their identity. Each exodus of Muslims corresponds to changing regimes. In 1978, during the Tatmadaw (Burmese Army) operation known as Nagamin about 220,000 Muslim refugees fled to Bangladesh. This operation was conducted in order to verify and determine 'nationality' and was carried out against possibly illegal Bengali migrants. As the newspapers said at the time, the atrocities in Arakan were against the "armed bands of Bengalis", "wild Muslim extremists", "rampaging Bengali mobs" ransacking indigenous Buddhist villages", and perceptions towards Muslims in the region were aggravated with incidents of violence and tyranny by the Burmese state and army (Grundy-Warr \& Wong 1997). Ever since the military came to power nationality has become significant to the citizenship and inclusion of the Rohingya. The Citizenship Law initiated by Burmese Social Programme Party (BSPP) in 1982 changes the citizenship regime to jus sanguinus. The government claimed that the National Register of Citizens (NRC) was not effective in proving citizenship and the residents in Burma would have to undergo a citizenship determination to verify nationality (Farzana 2017).

Citizenship was for the taingyin tha people and the non-taingyin tha. People considered indigenous to Myanmar, Thai-gyin-tha (citizenship at birth), nyan ngaing tha (for the non taingyin tha) or associated citizenship for those who were guest citizens or those who were allowed to be naturalised citizens, and those who were already citizens in 1982. These categories were applied by the state for granting citizenship. Identity became instrumental to how the state deprived the Rohingya of citizenship. Laws on citizenship by the state in 1980s alienated people through their documentation of identity. This affected the first exodus of Rohingya for most of the refugees had fled and were repatriated. The ruling Burmese Socialist Programme Party and popular opinion believed that aliens from China and East Pakistan were the cause of the operation (Kyaw 2017).

\subsection{Laws are passed against the freedom of minorities}

The 1982 Citizenship Law was brought in by the Burmese military rulers and denied citizenship to most people of Indian and Chinese decent. The law is different from the preceding Citizenship Act and it is based on the principle of jus sanguinis and identifies categories of citizens as full, associate, and naturalised. The Rohingyas do not appear in the list of 135 national races to whom full citizenship is given. The government of Myanmar does not recognise 'Rohingya' and the citizenship law does not recognise them as nationals belonging to the state. The associate citizenship category was granted to those whose application for citizenship was pending on the day the 1948 Citizenship Act came into force. The Naturalised citizenship could be given to those who provided "conclusive evidence" of entry and residence before Burma's independence on 4 January 1948, who could speak national languages well, and whose children were born in Burma. Few Rohingyas could fulfil all these requirements. The power to decide matters pertaining to citizenship was assigned to the government controlled 'Central Body' which resulted in Rohingya entitlements to citizenship not being recognised (Lewa 2009).

Discrimination also occurred through actions such as the severe restrictions imposed on movement, the banning of Rohingyas from civil service employment (including the education and health sectors), and the 1990 decision that made official marriage authorisation compulsory. Eventually, the authorities even stopped issuing Rohingya children birth certificates. Infringement of these rules can result in long prison sentences. Additionally, forced labour, arbitrary taxation, and confiscation of land, which are practiced elsewhere in Burma, are imposed on Rohingya in disproportionate manner (Lewa 2009).

Life, liberty, and the rights of the Rohingya people in Burma have become highly securitised with the freedom of movement being heavily restricted for Rohingya people. Some of the restrictions they face include being confined to villages. They have to apply for travel passes even to visit the neighbouring villages first exodus and they have to pay for the pass. Travel is restricted to North Arakan and even Sittwe, the capital of Myanmar, is declared off limits for them. The lack of mobility has had devastating consequences on their access the markets, employment opportunities, health facilities, and higher education. Those who over stay their travel pass are prevented from returning to their villages and names are deleted from family list. They are then obliterated administratively and compelled to leave Burma. Some Rohingyas have been prosecuted under national security legislation for travelling without permission. Rohingyas are forbidden to travel to Bangladesh, though some are able to do so using clandestine methods which has proven easier than going to the state capital. However, those who are caught could face a jail sentence there for their illegal entry. Many people who went to Bangladesh as patients seeking medical treatment were unable to return home and during their absence their names were removed from their family list. Once outside Burma, Rohingya are denied the right to return to their own country (Lewa 2009). 
State practices relating to registration and documentation since 1978 have also played a significant part. Such practices include the confiscation, destruction, nullification, and targeted non-issuance of identity documents (Brinham 2019). National verification is a process that showed the evidence of crimes against Rohingya. These "registration processes [have become] increasingly repressive, coercive and abusive since the mid-1990s, making survival for Rohingya in Myanmar more and more difficult" (Lewa 2009, 11).

\subsection{Atrocities and local discrimination}

Rohingya voices: Minister Shakir Alam:

\begin{abstract}
Coming here made me poor. He came right from Kolkatta to Hyderabad. Earlier, I had studied in Deoband Madrasa in India. When I came to Bangladesh I thought I would stay in Bangladesh or come to India. The police at Kolkatta gave me 2000 rupees seeing the children with me. All of India is good. This Government is good here.

Our government has committed numerous atrocities against our people, killed a lot of people in our village and raped a lot of people. We feel angry. If I have the good fortune to meet the Suu Kyi, I will tell how many atrocities have been committed. I am very angry. It might be better to die. We still have no card and we were given a home. It is a gift of the government on humanitarian grounds. They have given us help to live. Religious ministers face a great deal of atrocities. My village has been confronted with many atrocities. We have a temporary I.D.
\end{abstract}

\subsection{Sectarianism}

State laws in Myanmar go against the freedom of religion. The laws passed are the Religious Conversion Bill and the Monogamy Bill, or the so-called "race and religion" laws which came into force on August 21, 2015 (Human Rights Watch 2015). The religious conversion bill gives the state the provision to regulate religious professions and conversions. The Monogamy Bill prohibits a married person from entering into a second marriage or "unofficially" living with another person while still married. The 1982 Law of Citizenship privileges members of "national races" considered as indigenous by the state into three categories they are: (full) "citizen," "associate citizen" and "naturalized citizen." Meanwhile, the Buddhist Women's Special Marriage Law's purpose is "to enable the enjoyment of equal rights by Myanmar Buddhist Women and non-Buddhist men with respect to marriage, divorce, partition and guardianship of children and to give [them] effective protection" (International Commission of Jurists 2019). The race and religion laws are hostile to Rohingya culture as they allow the Rohingya to be singled out for citizenship based discrimination, religious profession and conversion discrimination, and restirctions on the freedom to marry and interracial marriages. These legislations form the social borders.

\subsection{Restrictions on freedom}

Rohingya voices: Farook (Interpreter with the UNHCR, Male):

That's because they say we don't belong there. We don't belong to Burma. Some years ago our ancestors had emigrated from Bangladesh, so we should not have Burmese citizenship. Yes, as well as the government. That was not just in 2012. This has been happening for 30 to 40 years. Slowly and slowly... one restriction and a second restriction. In 2012, it came in a big way. We were originally stripped of our citizenship in 1962. Before this we were citizens. We would be regarded as citizens by the government. As after this the restrictions that were brought upon us were like if you need to go to another city like for example if from Hyderabad you need to go to go to Secunderabad it falls in the same district you have to take permission. On paper, we have to take permission that we need to stay for a couple of days. We must take permission. This government has imposed restrictions on marriage. You can't just marry freely. To get married, we must submit a large application and after verification, they approve it. In the mosque no more than five people can come together and say their payors. We expected the situation to improve in 2013 and 2014. But that didn't happen. Because our country and our land are home to us. If we go to Bangladesh, they say that you are from Burma, if we go to India, they say that you are from Burma. Day after day, things went from bad to worse.

\section{State of Exceptionality for Rohingya refugees}

Jones (2009a) talks about the sovereign power of the state over the targeting of few individuals for exception, which occurs in particular places more than others. The task of understanding the state of exception is to identify the agents, targets, and spaces where sovereign power practices occur. In border enclaves the connections between bordering practices and sovereignty claims of India demonstrate the social benefits the sovereign state system has brought through the establishment of law and order and the devastating consequences it has caused by territorializing those basic social protections (Jones, 2009b). Rajaram and Grundy-Warr's (2007) work on "borderscapes" examines the structures of justice, security, and belonging that result from sovereignty, moral frameworks, and insurrectionary politics of belonging and un-belonging. This section outlines the discursive borders for Rohingya. The undocumented nature of the migration of stateless Rohingyas brings them into contact with the policies against them. These emerging conditions are shaping the impending anxiety of migration in South Asia. Newspapers reported that in 2019, 31 Rohingya families were stuck in No-Man's lands between the IndoBangladeshi borders (Aseanplus News 2019). In this event the two sovereign states had to choose who was 
responsible for the stateless people. People who have crossed the border can either be recognized or barred. This is an intermittent dilemma between sovereign countries over border-crossing refugees in a regional context where the refugee regime is weak.

The stigma of disease and exclusion during epidemics also affect Rohingya. The Rohingya refugees are affected by a disinformation campaign surrounding the COVID-19 pandemic (Bose 2020). They face the constant threat of eviction from the lands they are living on thus making the nature of shelter precarious for the Rohingya living in the Delhi settlement.

These groups of refugees have marginalized identities. The politics of identity overlapped with access to basic rights. With statelessness they are undocumented in terms of state recognition of their individual identity. These refugees are made dependant on refugee cards. The boundaries and borders of belonging and citizenship for the Rohingya refugees made them subject to control through securitisation regulations, rules in settlements, restricted work opportunities, limited access to education, and camp like life in settlements as well as other local restrictions. These social borders, boundaries, marginalizations, and marginalities have impacted on their daily lives.

The global protection regime across states in South and South East Asia and the global North have obstructed the effective protection of refugees and the development of sustainable solutions to the refugee problem, especially in regards to burden sharing through naturalisation or resettlement. Refugees face social exclusion and marginalization in the context of the robust institutional responses to the "urban refugees" in the cities of Delhi and Hyderabad which has had an adverse impact on refugee rights and well-being. The migration control on territories and people through securitization policies practices and actions has also had an impact on the human rights of the Rohingya refugees under globalization and flows which has resulted in the infringement of their citizenship and rights. As a result of the exercise of state sovereignty, pre-existing borders and extreme marginalities led to the further marginalization of refugees in the context of India. Do to their statelessness, the Rohingya rights to life are endangered by the implementation of deportation laws. Here in the margins, the state exercises to declare or treat person as unbelonging or illegal is failure to protect refugees and vulnerable groups at the society's margins.

\subsection{Boundaries and subjectivity}

They are subject to boundaries as refugees. Therefore they reside temporarily and without access to basic needs, particularly shelter and decent living conditions, their rights as refugees are violated. In the absence of a refugee regime they encounter the state with fears of deportation.

Inequalities give rise to socio-economic challenges. They form challenges that refugees are subjected to because of their legal status. They have to pay rent and rebuild the houses from time to time when they are asked to shift or move out. The challenges mainly exist because, under current circumstances of non-recognition, Rohingya refugees cannot survive freely.

The challenges of finding suitable work and earnings are meagre. The refugees face multiple challenges such as making an agreement with the employers for getting a job. Though work is informal they have no permanent informal employer-employee relationship because of their identity, their choices, and their preferences. They prefer to live in mobile way and go to find work whenever they get the opportunity. However, they are left with the choice of performing work at the bottom of the hierarchy where they must compromise on many aspects of the employer-employee relationship such as negotiating for longer terms with the employer, building a formal employer employee relationship, and obtaining more stable, continuous, and persistent form of work.

\subsection{Communal discourses on refugees}

The politics over the alleged immigration from Bangladesh led to the National Register of Citizens in the Indian State of Assam which excluded 19 lakh people after spending four years and billions of rupees (Choudhary 2021). The political bordering over "illegal immigrants" in Assam led to the building of detention camps to check alleged illegal immigration from Bangladesh and an NRC exclusion exercise resulted in massive human rights violations. Such ethnic politics and practices caused many people to become stateless. This is the outcome the ethno-national state that promotes a certain view of the mainstream based on politics of ethnicity and distinction. These are additional social borders that lead to the creation of marginalized groups and communities.

For the Rohingya, crossing the border means fearing ethnic violence and discrimination against 'Bengali immigrants' in their countries of origin. They have legitimate and substantive issues. In one incident, a Rohingya boy reported that he had to wait overnight in an isolated place to cross the border with India. He was told to run without looking back, even if someone throws a flashlight at him. The road of the border was muddy and full of grass and is 60 to 70 miles wide. In addition to large populated border areas and without personnel to find security, they also much navigate through additional legal obstacles. Social borders provide obstacles for the Rohingya who are fleeing to Bangladesh from Myanmar as immigrants face such communal campaigns. 


\section{Conclusion}

In a discussion about "cascades of violence", Braithwaite and D'costa (2018) examine a proposition stating that, "refugee and IDP flows further cascade violence... refugee camps become nodes of hopelessness and resentment for those whom they trap. This makes them ideal recruiting grounds for those with weapons and cash to enrol bereft young refugees into armed groups. In turn, these recruitment practices inside refugee camps make camps targets for atrocity by enemies of the recruiters" (138). On the other hand for Rohingya no country has been willing to resettle them in their own territory except for Bangladesh's plans to settle some of the refugees in the Bhasan Char, an isolated island in the Bay of Bengal. The official UN resettlement policy is for one percent of the people from the entire refugee group to be resettled in all areas of India. While some from the Rohingya look for their own means to resettle to the third country, a majority of Rohingya depend on the benefits of the government. Therefore, among the Rohingya they look for access to better educational, individual, and community development solutions in order to sustain their lives as refugees. Refugee protection is implemented in practice by the UN through the institutional mechanism of NGOs and civil society groups in Delhi and other places. There is limited funding and access from the UN for managing the refugees in Delhi and many of these aid organizations are unable to meet all the needs and concerns including the cost of shelter, health, education, other basic needs and day to day sustenance in a local level. State control has an impact on local integration. The Rohingya also have limited scope to work in restricted regions, sectors, and types of work.

The treatment of Rohingya refugees and marginalized groups in India is as if they are 'unauthorized'. The Rohingya are displaced people. The UNHCR assistance is based on humanitarianism. It is inadequate to meet challenges for dignified living conditions, right to development, and sustainable livelihoods due to which there are organizations that reach out to them. But the problem is that an outcome of politics and oppression, these humanitarian organizations consider the treatment of Rohingya as 'unauthorized' by state. Therefore these organizations are functioning within these established social barriers. Since they are stateless, the refugees are criminalized because they do not belong to anywhere. No nation or country says they are theirs. They have temporary IDs and no documentation with any government. They are forced to become either refugees or victims of traffickers.

This paper is on borders and the margins of Rohingya refugees. The marginal experience recounted by Rohingya refugees in India highlights the politics of social borders. The narratives and politics of the migrant or the immigrant are the borderscapes that affect the Rohingya refugees. The immigrant is being culturally and socially constructed based on politics of differentiation, oppression, subjugation, ill-treatment, and non-identification, as well as other parameters or stereotypes under the state. There are overarching political borders and actual concerns by the state about immigrants and the porous borders of states. The massive influx of Rohingyas refugees in Bangladesh is a burden to the local society. The vulnerability of the refugees and concerns over fostering terrorism affect national and international politics in the states. The attempts at securitization, detention, and confinement to the camps are the borderscapes for Rohingyas shaping state concerns regarding territorial integrity and sovereignty over population.

\section{Acknowledgement}

The author is grateful to a friend for accompanying her at the time of interviewing refugees for this paper.

\section{Note}

1 Rakhine State was geographically situated between Indian subcontinent and South East Asia. The Arakan region was a coastal kingdom of South East Asia. Arakan was ruled by different rulers in pre-colonial era such as the Marak $U$ kingdom in the 15th century. The Burmese rulers invaded Arakan from 1784 to 1824, the British ruled Arakan region after conquest of Burma in 1824.

\section{Works Cited}

All hyperlinks last accessed December 2021 unless specified.

Abdali, F. 2021. "The Continuous Exodus of Rohingyas in India" (Video). YouTube (July 8). https://www.youtube.com/ watch?v=BWrw9yu5ruw

AP. 2021. "Bangladesh sends hundreds more Rohingya refugees to island" The Times of India (November 25). https://timesofindia.indiatimes.com/world/south-asia/ bangladesh-sends-hundreds-more-rohingya-refugees-to-island/articleshow/87911155.cms

Aseanplus News. 2019. "Rohingya stuck in no man's land'” The StaR (January 22) https://www.thestar.com.my/news/ regional/2019/01/22/rohingya-stuck-in-no-mans-land

Bose, T. 2000. "COVID-19: Rohingya Refugees in India Are Battling Islamophobia and Starvation" The Wire (May).

Brenner, Y. 2019. "Rohingya migration to India: Patterns, drivers and experiences" Mixed Migration Centre. https:// mixedmigration.org/resource/rohingya-migration-to-india/

Brinham, N. 2019. "When Identity Documents and Registration Produce Exclusion: Lessons from Rohingya Experiences in Myanmar" LSE Blog. (May 10). https://blogs.Ise.ac.uk/ mec/2019/05/10/when-identity-documents-and-registration-produce-exclusion-lessons-from-rohingya-experiences-in-myanmar/

Chan, A. 2005. "The Development of a Muslim Enclave in Arakan (Rakhine) State of Burma (Myanmar)" SOAS Bulletin of Burma Research 3(2). 
Choudhary, S. 2021. "Borders Shift and People Move. So Who Are 'Illegal Immigrants', Really?" The Wire. (November 26). https://thewire.in/rights/ assam-border-bangladesh-illegal-immigrants

Cons, J. 2013. "Narrating boundaries: Framing and contesting suffering, community, and belonging in enclaves along the India-Bangladesh border" Political Geography 35: 37-46. https://doi.org/10.1016/j.polgeo.2012.06.004

Cons, J., \& R. Sanyal. 2013. "Geographies at the margins: Borders in South Asia-an introduction" Political Geography 35: 5-13. https://doi.org/10.1016/j.polgeo.2013.06.001

Dcosta, B., \& Braithwaite, J. 2018. Cascades of Violence: War, Crime and Peacebuilding Across South Asia. ANU Press.

Express News Service. 2018. "The Most Unwanted: A gripping account of Rohingya refugees living in India" The Indian Express. https://indianexpress.com/article/india/the-mostunwanted-a-gripping-account-of-rohingya-refugees-livingin-india-4464103/

Fakhrashrafi, M., J. P. Kirk, and E. Gilbert. 2019. "Sanctuary Inter/rupted: Borders, illegalization, and unbelonging" The Canadian Geographer / Le Géographe Canadien 63(1): 84-99. https://doi.org/10.1111/cag.12510

Farzana, K. F. 2017. Memories of Burmese Rohingya Refugees Contested Identity and Belonging. Palgrace Macmillan.

Fields, J., D. Bapat, S. Surbhi, I. Mohammed, S. K, R., and S. Jerath. 2019. "Understanding Contours of Refugee Resilience: Rohingya Refugees in Mewat in Haryana and Hyderabad in Telangana" Actionaid.

Gosh, P. 2016. Migrants, Refugees and Stateless in South Asia. SAGE Publications Pvt. Ltd.

Grundy-Warr, C., and E. Wong. 1997. "Sanctuary Under a Plastic Sheet-The Unresolved Problem of Rohingya Refugees" IBRU Boundary and Security Bulletin.

Human Rights Watch. 2015. "Burma: Discriminatory Laws Could Stoke Communal Tensions" (August 25). https:// www.hrw.org/news/2015/08/23/burma-discriminatory-laws-could-stoke-communal-tensions

IMPRI Impact and Policy Research Institute. 2021. "Special Lecture | Muang Zarni | Myanmar's Coup, Rohingya Genocide and Failed Democratization" (video). Youtube (May 5). https://www.youtube.com/watch?v=rfqELxwzgjg

IWM Vienna. 2019. "Ranabir Samaddar: Statelessness in South Asia” (Video). Youtube (March 12). https://www.youtube.

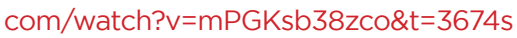

Jain, M. 2021. "Supreme Court Issues Notice On PIL Seeking To Ensure Food Security For Refugees \& Asylum Seekers" LiveLaw (November 29). https://www.livelaw.in/top-stories/ supreme-court-pil-issues-notice-food-security-refugeesasylum-seekers-186549

Jones, R. 2009a. "Agents of exception: Border security and the marginalization of Muslims in India" Environment and Planning D: Society and Space 27(5): 879-898. https://doi. org/10.1068/d10108

Jones, R. 2009b. "Sovereignty and statelessness in the border enclaves of India and Bangladesh" Political Geography 28(6): 373-381. https://doi.org/10.1016/j.polgeo.2009.09.006

Kyaw, N. N. 2017. "Unpacking the Presumed Statelessness of Rohingyas" Journal of Immigrant \& Refugee Studies 15(3): 269-286. https://doi.org/10.1080/15562948.2017.1330981

Leider, J. P. 2013. "Rohingya The name. The movement. The quest for Identity" in Nation Building in Myanmar. Yangon: Myanmar EGRESS/Myanmar Peace Center.

Lewa, C. 2008. "The Rohingya: Forced Migration and Statelessness" in Forced Migration in the South Asian Region: Displacement, Human Rights and Conflict Resolution, edited by O. Mishra. Manak Publications.

Lewa, C. 2009. "North Arakan: An open prison for the Rohingya in Burma" Forced Migration Review 32(Special Issue: Statelessness): 11-13. https://www.fmreview.org/sites/ fmr/files/FMRdownloads/en/FMRpdfs/FMR32/FMR32.pdf

Live Law News Network. 2021. "Supreme Court Allows Deportation Of Rohingyas To Myanmar As Per Procedure Prescribed" (April 21). https://www.livelaw.in/top-stories/ supreme-court-allows-deportation-of-rohingya-refugees-to-myanmar-as-per-procedure-prescribed-172302

Rajaram, P. K., and C. Grundy-Warr. 2007. BorderscapesHidden Geographies and Politics at Territory's Edge. University of Minnesota Press.

Samaddar, R. 2016. "Forced migration situations as exceptions in history?" International Journal of Migration and Border Studies 2(2): 99-118. https://doi.org/10.1504/ IJMBS.2016.075579

Thawnghmung, A. M. 2016. "The politics of indigeneity in Myanmar: Competing narratives in Rakhine state" Asian Ethnicity 17(4): 527-547. https://doi.org/10.1080/14631369. 2016.1179096

University of Luxembourg. 2015. Borderscape as an Interdisciplinary Concept, Call for Papers Symposium. Luxembourg.

Women's Refugee Commission. 2011. Bright Lights, Big City Urban Refugees Struggle to Make a Living in New Delhi. Women's Refugee Commission. https://reliefweb.int/ report/india/bright-lights-big-city-urban-refugees-struggle-make-living-new-delhi 